\title{
ULAMA BERBAGI OTORITAS: Fungsi dan Peran MUI Kota Padangsidimpuan dalam meningkatkan kesadaran dan budaya hukum masyarakat
}

\author{
Ahmatnijar \\ (Lecturer of Sharia and law Sciences Faculty at State College for Islamic Studies \\ Padangsidimpuan) \\ Email: ahmatnijar.iain@gmail.com
}

\begin{abstract}
The authority of MUI Padangsidimpuan in function theoretically is as container deliberation, silaturrahmi the scholars, zuama and Muslim scholars in protecting the people, develop and practice the teachings of Islam, raising ukhuwah Islamiyah in Islamic life. As a container representing Muslims in the relationship and interreligious consultations and giving fatwas to the Muslims and the government, whether requested or not requested. The authority of MUI Padangsidimpuan to deal with globalization, liberalization, institutions that have authority, other Islamic religious social organization. For that function should be developed according to the quality and quantity of life issues are growing. While the role of the authorities practically have shared with agencies that have the authority and the authority that created pure, so the authority was scattered and terfungsikan by other agencies.
\end{abstract}

Key Words: Authority, functions and role of the of MUI Padangsidimpuan

\section{Abstrak}

Otoritas MUI Kota Padangsidimpuan dalam menjalankan fungsi secara teoritis adalah sebagai wadah musyawarah, silaturrahmi para ulama, zuama dan cendekiawan muslim dalam mengayomi umat, mengembangkan dan mengamalkan ajaran Islam, menggalang ukhuwah Islamiyah dalam kehidupan yang Islami. Sebagai wadah yang mewakili umat Islam dalam hubungan dan konsultasi antar umat beragama serta pemberi fatwa kepada umat Islam dan pemerintah, baik diminta maupun tidak diminta. Otoritas MUI Kota Padangsidimpuan tengah berhadapan dengan arus globalisasi, liberalisasi, lembaga-lembaga yang memiliki otoritas, organisasi sosial keagamaan Islam lainnya. Untuk itu fungsinya harus dikembangkan sesuai kualitas dan kuantitas persoalan hidup yang semakin berkembang. Sementara dalam hal peran secara praktis telah berbagi otoritas dengan lembaga yang memiliki otoritas murni dan otoritas yang diciptakan, sehingga otoritas itu terpencar dan terfungsikan oleh lembaga lain.

Kata Kunci: Otoritas, fungsi dan peran MUI Kota Padangsidimpuan

\section{PENDAHULUAN}

Otoritas menunjukkan pada konsep pentingnya pengaruh seseorang individu, sistem pandang atau sebuah organisasi yang timbul dari kualitas tertentu atau dari pelayanan yang 
diberikan. ${ }^{1}$ Dalam Kamus Besar Bahasa Indonesia otoritas disebutkan dalam beberepa makna yakni pertama, kekuasaan yang sah yang diberikan pada lembaga dalam masyarakat yang memungkinkan para pejabatnya menjalankan fungsinya, kedua, hak untuk bertindak, ketiga, kekuasaan/wewenang, keempat, hak melakukan tindakan atau hak untuk membuat peraturan untuk memerintah orang lain. ${ }^{2}$

Otoritas bisa juga dimaknai dengan keahlian dan hak memerintah atau mengendalikan orang lain. Keyakinan terhadap seseorang yang dianggap memiliki keahlian pada bidang tertentu akan membuat orang yang meyakini tersebut terpengaruh dengan pendapat itu. Otoritas mirip dengan kekuasaan, meski otoritas tidak sepenuhnya dapat disamakan dengan kekuasaan, karena otoritas tidak pernah menggunakan medium rayuan, kekerasan, dan apalagi paksaan untuk mengikuti pendapatnya. Tetapi ketundukan pada keahlian khusus yang dimilikinya membuat orang lain secara suka rela akan melakukan sesuai pendapat atau ungkapannya.

Dalam pengertian yang lebih eksklusif, otoritas membuat orang tidak perlu mempertimbangkan beragam alasan dan kemudian memutuskan untuk mengikuti contoh dalam hal ini adalah kepemilikan otoritas Nabi. Para sahabat tidak perlu dan bahkan hampir tidak pernah meminta argumentasi dari Nabi untuk meyakinkan mereka atas suatu aturan hukum untuk diikuti. Otoritas yang dimiliki Nabi sudah cukup sebagai sumber legitimasinya ${ }^{3}$. Meski masih perlu perbincangan lebih jauh tentang otoritas murni dan otoritas yang diciptakan, yang pasti Nabi memiliki otoritas tunggal dalam pembinaan dan pengembanga hukum Islam.

Ketika ulama yang dinormativisasi sebagai pewaris Nabi, sehingga otoritas Nabi meng-emanasi kepada ulama. Pada saat demikian otoritasnya secara normatif sudah diakui. Di Indonesia ada dikenal Majlis Ulama Indonesia (MUI) yang pada awal kelahirannyamemiliki otoritas yang kredibel, sehingga tidak salah apabila muncul berbagai atribusi yang diberikan kepada lembaga ini sebagai bentuk apresiasi seperti cultural broker, political enterpreneur, religious schoolar, social leader. ${ }^{4}$ Atribusi ini terkadang dikaitkan dengan hierarki struktural kepengurusannya mulai dari tingkat pusat, wilayah, daerah dan Kecamatan yang seolah menggambarkan adanya otoritas yang diciptakan dalam tubuh MUI.

Sebagai pewaris Nabi, lembaga ini -boleh jadi khusus di negara Indonesia-berfungsi sebagai:

${ }^{1}$ Loren Bagus, Kamus Filsafat, (Jakarta: Gramedia Pustaka Utama, 2000), hlm. 768

${ }^{2}$ Kamus Besar Bahasa Indonesia (Jakarta: Balai Pustaka, ), hlm. 244

${ }^{3}$ Pasca Nabi, perbincangan otoritas dalam hal-hal tertentu disamakan dengan legitimasi, sehingga level antara hujjah - batil dalam hal ini telah berkembang mencapai tujuh level. Lihat Jasser Audah, Maqasid al-Syariah in Philosophy of Islamic Law: A System Approach. (London-Washington, IIIT, 2007), hlm.5-60

${ }^{4}$ Qomarul Huda, "Otoritas Fatwa dalam Konteks Masyarakat Demokratis: Tinjauan atas Fatwa MUI Pasca Orde Baru" dalam M. Atha Mudzhar, dkk, Fatwa Majlis Ulama Indonesia (MUI) dalam Perspektif Hukum dan Perundang-undangan, (Jakarta: Kemenag dan MUI Pusat, 2012), hlm. 617-9 
1. Sebagai wadah musyawarah para ulama, zuama dan cendekiawan muslim dalam mengayomi umat dan mengembangkan kehidupan yang Islami.

2. Sebagai wadah silaturrahmi para ulama, zuama dan cendekiawan muslim untuk niengembangkan dan mengamalkan ajaran Islam dan menggalang ukhuwah Islamiyah.

3. Sebagai wadah yang mewakili umat Islam dalam hubungan dan konsultasi antar umat beragama.

4. Sebagai pemberi fatwa kepada umat Islam dan pemerintah, baik diminta maupun tidak diminta. ${ }^{5}$

Dalam Pedoman Dasar MUI, bab IV Pada Pasal 6 tentang Usaha diutarakan bahwa untuk mencapai tujuannya, Majelis Ulama Indonesia melaksanakan usaha-usaha:

1. Memberikan bimbingan dan tuntunan kepada ummat Islam agar tercipta kondisi kehidupan bergama yang bisa menjadi landasan yang kuat dan bisa mendorong terwujudnya masyarakat yang berkualitas (khaira ummah).

2. Merumuskan kebijakan penyelenggaraan dakwah Islam, amar ma'ruf nahi munkar untuk memacu terwujudnya kehidupan beragama dan bermasyarakat yang diridloi oleh Allah SWT.

3. Memberikan peringatan, nasehat dan fatwa mengenai masalah keagamaan dan kemasyarakatan kepada masyarakat dan pemerintah dengan bijak (hikmah) dan menyejukkan.

4. Merumuskan pola hubungan keummatan yang memungkinkan terwujudnya ukhuwah Islamiyah dan kerukunan antar umat beragama dalam memantapkan persatuan dan kesatuan bangsa.

5. Menjadi penghubung antara ulama dan umara (pemerintah) dan penterjemah timbal balik antara pemerintah dan umat guna mencapai masyarakat berkualitas (khaira ummah) yang diridhai Allah SWT (baldatun thayyibatun wa rabbun ghafur).

6. Meningkatkan hubungan serta kerjasama antara organisasi, lembaga Islam dan cendekiawan muslim, serta menciptakan program-program bersama untuk kepentingan umat.

7. Usaha/kegiatan lain yang sesuai dengan tujuan organisasi.

Selama periode Orde Baru, peran dan fungsi MUI sangat efektif dalam mengemban tujuannya karena dekat dengan masyarakat. Fatwa-fatwa yang disampaikan MUI lebih mendapat perhatian dan pengaruh bagi masyarakat serta dijadikan pedoman bagi masyarakat maupun pemerintah. ${ }^{6}$ Tentu saja ini karena didukung oleh otoritas yang mantap sebagai motor penggerak dan percepatan dalam meningkatkan kesadaran dan membangun budaya masyarakat sebagai pelengkap identitasnya sebagai manusia. Tetapi sejak keluarnya 
fatwa MUI tentang aliran sessat tahun 1980-an, tahun 2005 pelarangan menerima dan mengikuti faham sekularisme, pluralisme, dan liberalisme, dan tahun 2009 fatwa tentang golput, sekte Ahmadiyah, maka otoritas MUI mengalami pasang surut. Disinilah mulai terlihat ada celah besar yang perlu dikaji dan diteliti lebih dalam sekitar otoritas MUI itu sendiri. Tentu saja tidak terlalu jauh dengan MUI Kota Padangsidimuan. Untuk itu otoritas MUI Kota Padangsidimpuan juga sangat tepat untuk diteliti dalam hal peningkatan kesadaran dan budaya hukum masyarakat, karena otoritas sosiologis suatu lembaga akan berbeda antar waktu dan tempat. ${ }^{7}$

MUI memegang peranan penting dalam sejarah, pembentukan masyarakat Islam Indonesia pada hampir semua aspek kehidupan --sosial, politik, budaya, dan pendidikantentu saja dengan fokus utama dalam bidang keagamaan. MUI Kota Padangsidimpuan memang tidak memiliki otoritas membuat fatwa, tetapi MUI Kota Padangsidimpuan berhak merekomendasikan berbagai persoalan sosial keagamaan ke MUI Propinsi Sumatera Utara serta berkewajiban mensosialisasikan fatwa-fatwa yang dihasilkan MUI Propinsi Sumatera Utara.

Seperti diungkapkan sebelumnya bahwa pemerintah akan sangat terbantu menemukan solusi alternatif dari berbagai persoalan bangsa dengan kehadiran dan bantuan MUI. Demuikian juga kehadiran MUI Kota Padangsidimpuan turut membantu agenda pemerintah Kota Padangsidimpuan. Dalam banyak hal seperti MUI Kota Padangsidimpuan telah mengajukan draft Ranperda tentang larangan menjual dan meminum-minuman keras, larangan beternak babi di tempat pemukiman, kewajiban baca tulis al-Qur'an, memakai busana muslim telah disahuti dan menjadi Peraturan Daerah (Perda) Kota Padangsidimpuan. Bahkan dalam bidang politik, meski hal ini tidak merupakan core dari peran dan fungsi MUI Kota Padangsidimpuan, untuk tidak mengatakan seluruh kelembagaan MUI, kurang lebih $85 \%$ otoritasnya telah dimanfaatkan oleh elit politik untuk mendukung keinginan mereka terutama saat menjelang pemilihan kepala daerah. ${ }^{8}$

\section{FOKUS KAJIAN}

MUI Kota Padangsidimpuan turut berperan dalam sejarah pembentukan masyarakat Islam pada hampir semua aspek kehidupan --sosial, politik, budaya, dan pendidikan-dan tentu saja dengan fokus utama dalam bidang keagamaan. Dengan mempertimbangkan banyak hal, maka tulisan ini difokuskan pada:

\begin{tabular}{|c|c|c|}
\hline No & Soial Keagamaan & Keterangan \\
\hline 1 & $\begin{array}{l}\text { Penentuan awal } \\
\text { Ramadhan dan hari raya }\end{array}$ & $\begin{array}{l}\text { Umat Islam seharusnya taat pada pemerintah } \\
\text { yang sah dan ulil amri dalam berbagai hal }\end{array}$ \\
\hline
\end{tabular}

\footnotetext{
${ }^{7}$ April Carter, Authority and Democraty, diterjemahklan oleh Sahat Simamora, (Jakarta: Rajawali, 1985), hlm.111. ${ }^{8}$ SP, MUI Kota Padangsidimpuan, wawancara di Kota Padangsidimpuan pada tanggal 11 Maret 2015.
} 


\begin{tabular}{|c|c|c|}
\hline & $\begin{array}{l}\text { Id. Ini Terkait halal } \\
\text { haramnya berpuasa pada } \\
\text { hari tersebut }\end{array}$ & $\begin{array}{l}\text { termasuk dalam penetuan awal puasa } \\
\text { Ramadhan. Terkait dengan metode hisab dan } \\
\text { ruyat, H. Amsir Soleh Siregar } \\
\text { mengungkapkan bahwa metode hisab } \\
\text { merupakan langkah awal untuk menentukan } \\
\text { kapan ruyah dilaksanakan, bukan metode } \\
\text { ruyah sebagai penetapan awal Ramadhan } \\
\text { tanpa perlu di-ruyah lagi. }\end{array}$ \\
\hline 2 & $\begin{array}{l}\text { Zakat Produktif ini } \\
\text { merupakan Alternatif } \\
\text { peningkatan } \\
\text { kemaslahatan ekonomi } \\
\text { umat }\end{array}$ & $\begin{array}{l}\text { Deputi Gubernur Bank Indonesia Halim } \\
\text { Alamsyah mengatakan potensi zakatIndonesia } \\
\text { baru tergarap sebanyak 1,4\% dari sumber yang } \\
\text { ada sebesar sekitar } 217 \text { trilyun, atau sekitar } 22 \\
\text { milyar Dollar AS. Sedangkan potensi zakat di } \\
\text { dunia bisa mencapai } 600 \text { miliar Dollar AS. }{ }^{10}\end{array}$ \\
\hline & Sosial Kemasyarakatan & \\
\hline 3 & 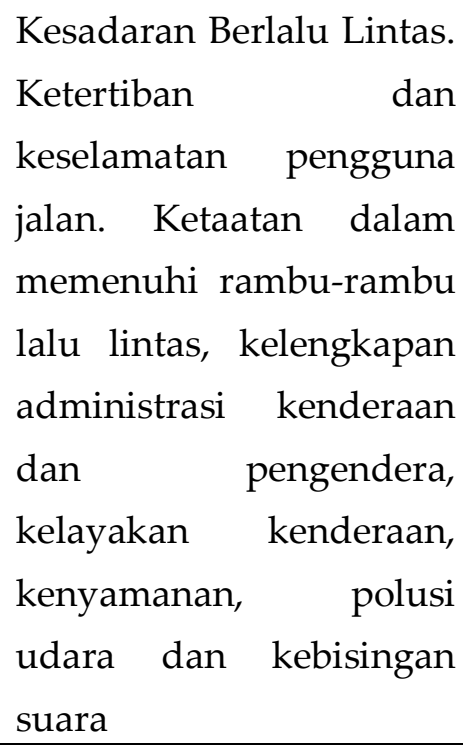 & $\begin{array}{l}\text { MUI mitra pemerintah. Pemerintah sadar } \\
\text { bahwa persoalan yang dihadapi bangsa } \\
\text { Indonesia tidak dapat diselesaikan tanpa } \\
\text { melibatkan peran ulama, tentu saja termasuk } \\
\text { MUI. }{ }^{11} \text { Kesadaran tertib lalu lintas masyarakat } \\
\text { menurut Wakapoldasu Brigjen Pol. Drs. Ilham } \\
\text { Salahuddin, SH, M.Hum, masih rendah. Ini } \\
\text { pemicu tingginya angka kecelakaan di jalan } \\
\text { raya. Selama Januari 2015saja tercatat } 360 \\
\text { orang tewas akibat kecelakaan lalu lintas. }{ }^{12}\end{array}$ \\
\hline 4 & $\begin{array}{l}\text { Jam Belajar Masyarakat. } \\
\text { Mencerdaskan bangsa, } \\
\text { termasuk dalam } \\
\text { peningkatan kesadaran } \\
\text { dan budaya hukum } \\
\text { masyarakat }\end{array}$ & $\begin{array}{l}\text { Posisi budaya hukum sangat penting, karena } \\
\text { melalui kultur yang kuat, maka penegakan } \\
\text { hukum menjadi semakin mumpuni. }{ }^{13}\end{array}$ \\
\hline
\end{tabular}

${ }^{9} \mathrm{HAS}, \mathrm{MUI}$, wawancara di Padangsidimpuan, 12 Nopember 2015.

${ }^{10}$ Harian Waspada, Agustus 2014, hlm. 1

${ }^{11}$ Qomarul Huda, “Otoritas....", hlm. 151

${ }^{12}$ Harian Waspada, Kamis, 2 April 2015, hlm. A3

${ }^{13}$ Komisi Yudisial RI, Problematika Hukum dan Peradilan di Indonesia, (Jakarta: KYRI, 2014), hlm. 241. 
Sehingga dari tabel di atas akan dipaparkan otoritas MUI Kota Padangsidimpuan dalam meningkatkan kesadaran dan budaya hukum masyarakat.

\section{KAJIAN TEORITIS}

\section{Otoritas}

Otoritas secara sederhana dapat disebutkan kewenangan. Otoritas dalam Islam berawal dari peristiwa pembedahan dada Nabi Muhammad SAW oleh Malaikat Jibril untuk membuang "kotoran hitam" dan memasukkan hikmah ke dalamnya. Dengan hilangnya kotoran dan "dosa" dari dalam dada Nabi, kemudian diganti dengan hikmah, maka otomatis memunculkan suatu potensi atau kekuatan yang mengandung bobot daya paksa, kewenangan, otoritas. Sering disebut dengan istilah otoritas transendental. Ini terjadi saat Nabi masih remaja. ${ }^{14}$ Perilaku Nabi yang tidak pernah salah ini merupakan awal lahirnya otoritas kenabian dalam mendukung proses pewahyuan, dan infallibility ${ }^{15}$ ini merupakan pondasi dasar bagi lahirnya otoritas kerasulan dan hal-hal lain yang terkait dengan kenabian. Infallibility juga memberikan kekuatan justifikasi bagi interpreter berikutnya.

Setelah Nabi wafat, otoritas transedental beralih ke otoritas empirik secara ijma' di tangan sahabat sebagai kelas penafsir agama yang otoritatif. ${ }^{16}$ Otoritas sahabat ini muncul karena secara keilmuan mereka paham betul dengan hukum Islam yang dibawa oleh nabi, mereka intens menemani nabi ke mana-mana, sehingga ajaran agama Islam lebih mereka pahami dan bahkan telah terinternalisasi dlam diri mereka. Disamping itu para sahabat kebanyakan orang Arab yang sudah tahu karakter dan budaya Arab itu sendiri. Sahabat bisa mendialogkan teks yang menggunakan bahasa mereka, bahasa Arab, dengan kondisi objektif di lapangan. Studi kasus, asbab al-nuzul dan asbab al-wurud turut membantu mereka dalam mendialog-kreatifkan teks dengan kondisi objektif serta nilainilai tradisi yang hidup di lapangan.

Pada masa kejayaan Islam I masa Bani Abbas, metode pengembangan hukum Islam sangat variatif. Satu diantaranya yang dinilai penuh dinamika adalah dengan metode jadal ${ }^{17}$ dalam bahasa Indonesia lebih dikenal dengan ungkapan debat. Jadal menuntut prasyarat yakni pengusaan literatur dan bahan kajian secara ilmiah. Ini menjadi wilayah akademik. Dengan kemampuan menemukan dalil dan mengembangkan argumentasi berdasarkan postulat yang kuat, masing-masing pihak mulai membangun

\footnotetext{
${ }^{14}$ Daniel W. Brown, Rethinking Tradition in Modern Islamic Thought, (Cambridge: Cambridge University Press, 1996), hlm. 61

${ }^{15}$ Ahmad Fanani, “Otoritas dalam Hukum Islam: Antara Tranformasi dan Krisis dalam Sistem Negara Moderen" Justitia, vol. 7 No. 1/ Januari - Juni, 2010, hlm. 28

${ }^{16}$ Zaenal Arifin, dkk (ed), Filsafat..., hlm.130

${ }^{17} \mathrm{Kita}$ bandingkan dengan metode muzakarah lebih mengarah pada satu kesepakatan, sementara jadal adalah upaya pencarian argumentasi tanpa harus menyeberang unutk mengikuti pendapat lawan diskusi. QS... membuat role play dengan wajadilhum billati hiya ahsan.
} 
otoritas keilmuannya secara akademik, mulai menyakinkan pihak lain dan tentu saja mulai menguatkan pendapatnya di mata peserta yang lain.

Jika otoritas akademik ini ditarik pada wilayah hukum Islam secara khusus, otoritas pemahaman hukum Islam seharusnya tidak muncul secara sepihak, apalagi kemunculan otoritas itu berasal dari dalam kelompok itu sendiri. Otoritas pemahaman hukum Islam idealnya berawal dari terjaganya infallibility, ${ }^{18}$ sehingga muncul pengakuan dari pihak luar.

2. Majelis Ulama Indonesia (MUI)

Induk dari ungkapan ini adalah ulama. Dari segi etimologis, kata ulama (علماء) adalah bentuk plural dari kata عالم, yang artinya orang-orang yang mengerti, orang yang berilmu, atau orang yang berpengetahuan. Dengan pengertian ini, ulama adalah para ilmuan, baik di bidang agama, humaniora, sosial, dan kealaman. Dalam perkembangannya kemudian, pengertian ini menyempit dan hanya dipergunakan oleh ahli agama. Karenanya, secara terminologis, ulama berarti orang yang ahli dalam hal atau pengetahuan agama Islam. Dengan pengertian ini, maka yang dimaksud dengan ulama adalah khusus orang yang mendalam ilmunya tentang agama Islam dengan segala cabangnya, seperti tafsir, hadis, fikih, tauhid, nahu, sharaf, dan balagah.

Indonesia mengenal suatu lembaga wadah musyawarah para ulama, zuama, dan cendikiawan muslim dalam mengayomi umat dan mengembangkan kehidupan yang islami dengan nama lembaga Majelis Ulama Indonesia yang disingkat dengan sebutan MUI. Otoritas yang dimiliki MUI lebih dapat menunjukkan perannya dalam upaya percepatan peningkatan kesadaran dan budaya hukum masyarakat, karena psisi budaya hukum sangat penting, karena melalui budaya hukum yang kuat akan tercipta suasana penegakan hukum yang semakin mumpuni. ${ }^{19}$

\section{Kesadaran dan Budaya Hukum}

Kesadaran hukum muncul dalam praktek sosial ditempa di dalam dan di luar peristiwa-peristiwa sosial. Oleh karena itu kesadaran hukum merupakan operasi struktur sosial, karena kesadaran hukum seseorang dapat bervariasi sepanjang masa walaupun tetap mengacu pada empat indikator kesadaran hukum, yakni pengetahuan tentang hukum, pemahaman tentang hukum, sikap terhadap hukum, dan perilaku hukum.

Lalu kesadaran hukum masyarakat yang diharapkan muncul dari dukungan ototritas MUI Kota Padangsidimpuan adalah masyarakat dapat mengetahui, memahami, memiliki

${ }^{18}$ Daniel W. Brown, Rethinking Tradition in Modern Islamic Thought, (Cambridge: Cambridge University Press, 1996), hlm. 61. Perilaku Nabi yang tidak pernah salah merupakan awal lahirnya otoritas kenabian dalam mendukung proses pewahyuan, dan infallibility ini merupakan fondasi dasar bagi lahirnya otoritas kerasulan dan hal-hal yang terkait dengan kenabian. Infallibility juga memberikan kekuatan justifikasi bagi interpreter berikutnya.

${ }^{19}$ Komisi Yudiasial RI, Problematka Hukum dan Peradilan di Indonesia, (Jakarta: KYRI, 2014), hlm. 241 
sikaf positif, serta berperilaku sesuai aturan hukum Islam dalam berbagai bidang kehidupan setelah diadakannya sosialisasi, pengawalan, dan pengawasan hukum.

Terkait dengan budaya hukum, budaya hukum dimaknai sebagai kekuatan berakal baik, halus, indah, santun. Tentu saja budaya dapat diartikan sebagai seperangkat pemikiran, gagasan, ide yang baik. Secara sosiologis, budaya hukum diartikan sebagai seperangkat nilai, norma masyarakat yang menjadi pedoman berfikir, berucap, berperilaku, bertindak bagi sebagian besar masyarakat dalam klehidupan sehari-hari. Dalam konteks hukum, budaya hukum adalah interaksi fungsional dari unsur-unsur hukum, mulai dari substansi hukum, sstruktutr hukum sampai pada budaya hukum.

Substansi hukum adalah putusan hukum dari seseorang yang mengaktegorikan suatui tindakan kepada benar atau salah. Struktur hukum terdapat hakim, jaksa, pengacara, terdakwa, saksi, penitera pada satu sub, sementara pada sub sistem lain ada hukum acara, aturan perundang-undangan yang menjadi dasar memutus. Jadi yang dimaksud dengan budaya hukum adalah proses interaksi fungsional antara berbagai unsur hukum yang mengakomodasi kekuatan-kekuatan sosial, kekuatan-kekuatan hukum yang hidup dalam masyarakat berserta hukum formal. ${ }^{20}$

MUI dengan otoritasnya diharapkan dapat melakukan interaksi fungsional yang menjangkau seluruh sub sistem hukum, mulai dari pemahaman terhadap sumber hukum, pembuat aturan hukum, pendampingan, pengawasan terhadap pembuat, pengwas, dan pengguna huku untuk mendapatkan output dan outcomes hukumyang berkemaslahatan umum. Posisi budaya hukum sangat penting, ksarena melaui kultur yang kuat, maka penegakan hukum menjadi semakin mumpuni. ${ }^{21}$

\section{KERANGKA TEORI}

Setiap lingkup realitas kehidupan baik keluarga, politik, pekerjaan, pendidikan, dan sebagainya masing-masing membutuhkan tipe-tipe otoritas yang berbeda ataupun yang bersifat khusus. ${ }^{22}$ Terdapat dua bentuk ototritas yakni otoritas murni dan otoritas yang diciptakan. Kementerian Agama sejak kabinet pertama pasca kemerdekaan, ia tidaklah kemudian menjadi pemegang otoritas Islam, dan apalagi kementerian ini tidaklah khusus berkenaan dengan urusan masyarakat Islam, tetapi juga komunitas-komunitas agama lain. MUI Kota berada pada otoritas murni yang tidak didukung oleh birokrasi dan tidak memiliki pagu anggaran dalam lingkungan eksekutif.

Pada awalnya di masa kesultanan, otoritas agama berpusat pada ulama yang berada pada lembaga-lembaga pendidikan Islam, seperti dayah, surau, dan pesantren. Sejak masa

${ }^{20}$ Ade Saptomo,"Budaya Hukum Indonesia yang Mendukung Pembangunan Hukum Nasional" dalam Komisi YUdisial RI, Problematika Hukum dan Peradilan di Indonesia, (Jakarta: KYRI, 2014), hlm. 241

${ }^{21}$ Komisi Yudisial RI, Problematika Hukum dan Peradilan di Indonesia, (Jakarta: KYRI, 2014, hlm. 241

${ }^{22}$ April Carter, Authority and Democracy, diterjemahkan oleh Sahat Simammora, (Jakarta: Rajawali, 1985), hlm. 99 
kolonial Belanda, otoritas agama menjadi terpencar di antara ulama yang berada pada lembaga-lembaga Islam dengan ulama yang berada dalam struktur pemerintahan kolonial. Pada dasawarsa-dasawarsa awal abad 20, pemencaran otoritas agama kian meningkat dengan munculnya berbagai organisasi Islam sejak dari Jami'at Khair, Muhammadiyah, NU, dan seterusnya. Sejauh menyangkut otoritas dalam bidang fikih, organisasi-organisasi ini memiliki lembaga fatwanya masing-masing yang tidak saling mengikat satu sama lain. ${ }^{23}$ Ditambah serangan globalisasi dan liberalisasi, maka otoritas ulama/MUI menguatkan statemen bahwa otoritas dalam satu suasana tidak harus menghasilkan sikap yang sama dalam suasana yang lain.

\section{METODE PENELITIAN}

1. Jenis Penelitian

Penelitian ini tergolong pada penelitian kualitatif, yakni ingin menggambarkan fenomena sosial dengan menggunakan pendekatan kualitatif bermaksud menggambarkan setting sosial apa adanya tanpa ada rekayasa untuk mendapatkan latar aslinya. Dalam penelitian kualitatif keaslian dan kepastian merupakan faktor yang sangat ditekankan. $^{24}$

\section{Metode dan Pendekatan}

Penelitian ini menggunakan metode deskriptif kualitatif. Paradigma penelitian kualitatif berparadigma alamiah dan ekspansionis. ${ }^{25}$ Menurut paradigma ini setiap fenomena sosial harus diungkap secara holistik yakni kriteria kualitas lebih ditekankan pada relevansi, yakni signifikansi dan kepekaan peneliti terhadap lingkungan sebagaimana adanya. Peneliti mengamati gejala sosial secara alamiah dan mengembangkannya sampai titik jenuh.

Sementara pendekatan yang digunakan adalah filosofis-sosiologis.

a. Secara filosofis, adanya Hadis yang mengungkapkan al-ulama warasat al-anbiya' bahwa peran dan fungsi ulama sebagai pewaris Nabi. Pewaris Nabi dimaksudkan bukan dari aspek trans material, tetatpi lebih pada peran keberlangsungan visi-misi kenabian sebagai penyempurna akhlak manusia (innama bu'istu liutammima makarim al-akhlaq). Term moral yang dipadankan dengan kosa kata akhlak, dalam Lisan al'Arab diungkapkan bahwa inti dari akhlak itu bersumber dari akhlak itu sendiri, tetapi jabarannya mencaku ruang lingkup yang luas. ${ }^{26}$

Bahasan ini akan dikaitkan dengan traveling theory.

${ }^{23}$ Azyumardi Azra, Republika, 6 Januari 2011

${ }^{24}$ M. Sayuthi Ali, Metodologi Penelitian Agama: Pendekatan, Teori, dan Praktek (Jakarta: PT Raja Grafindo Persada, 2002), hlm. 59

${ }^{25}$ M. Sayuthi Ali, Metodologi...hlm. 59

${ }^{26} \mathrm{Ibnu}$ Manzur, Lisan al-'Arab, (Beirut: Dar al-Sadr, 1990), hlm. 89 
Traveling theory merupakan konstruk teoritik yang menerangkan bahwa suatu ide atau gagasan mngalami perpindahan dari orang perorang, dari satu situasi ke situasi lain dan dari satu periode ke periode lain. ${ }^{27}$ Kehidupan budaya dan intelektual sangat tergantung pada ide atau gagasan. Fokus utama dari teori perjalanan ini adalah cara-cara dimana ide atau gagasan mengalami transformasi seiring dengan proses trans-lokal ide tersebut. Gagasan yang dibawa oleh MUI berawal dari nilai dan ide yang dibawa oleh Nabi Muhammad SAW di Semenanjung Arabia. Kemudian gagasan dan ide tersebut di-trans-lokal-kan ke Indonesia. Dalam perjalanannya, ide dan gagasan tersebut berhadapan dengan gagasan kultur lokal Indonesia. Memang hampir seluruh ide merupakan trans-lokal, kemudian mengkristal dan menjadi dogma serta praktek sosial.

Ada empat tahapan yang dilalui dalam proses perjalanan dalam sebuah ide yakni:

1. Tempat asli (a point of origin). Ide dan gagasan Islam dengan tempat asli di Saudi Arabia.

2. Tindakan perjalanan ide itu sendiri (distance transversed).

3. Pertemuan ide atau gagasan dengan budaya baru di tempat baru akan mengalami berbagai kemungkinan, seperti resepsi, akulturasi, perbedaan, pertentangan dan bahkan ada yang berlawanan dengan budaya lokal. Proses adaptasi dan negosiaisi pun intens berlangsung.

4. Tahap transformasi setelah lolos dari sergapan budaya lokal dan penganut agama dan keercayaan lain.

b. Sedangkan secara sosiologis tergambar bahwa dari studi historis-empiris terhada fenomena keagamaan yang diperoleh masukan bahwa agama sesungguhnya sarat dengan berbagai "kepentingan" yang menempel dalam ajaran atau batang tubuh ilmu-ilmu agama itu sendiri. Hampir semua agama memunyai "institusi" atau "organisasi" pendukung yang memperkuat, menyebarkan ajaran agama yang diembannya. Institusi dan organisasi keagamaan tersebut ada yang bergerak dalam wilayah sosial budaya, sosial kemasyarakatan, pendidikan, politik, ekonomi, dan sebagainya. ${ }^{28}$ Ini berkaitan dengan fenomenologi.

Dalam konteks fenomenologi, eksplorasi terhadap pengalaman pelaku suatu peristiwa secara kompleks dan pemaknaan terhadap pengalamannya merupakan perioritas untuk mempresentasi pengetahuan secara deskriptif dan sistematis kepada publik.

\footnotetext{
${ }^{27}$ Masdar Hilmy, Akar-Akar Trans-nasionalisme dalam Hizbut Tahrir Indonesia" dalam Islamica: Jurnal Studi Keislaman, Vol. 6, No. 1, September 2011, hlm. 4

${ }^{28}$ Kata Pengantar yang disampaikan M. Amin Abdullah dalam Ahmad Norma Permata, (ed), Metode Studi Islam, (Yogyakarta: Pustaka Pelajar, 2000), hlm. 2
} 


\section{Sumber dan Instrumen Pengumpul Data}

Secara umum sumber data penelitian kualitatif ialah tindakan dan perkataan manusia dalam suatu latar yang bersifat alamiah. Sumber data lain adalah bahan-bahan perpustakaan yang dijadikan sebagai kajian dan landasan teori serta kerangka konseptual. Penelitian kualitatif bertolak dari asumsi tentang realitas atau fenomena sosial yang bersifat unik dan kompleks. Regularitas atau pola tertentu dengan variasi yang beragam akan ditemukan di lapangan. Untuk itulah data dan informasi harus ditelusuri sedalam dan seluas mungkin sesuai dengan variasi yang ada melalui wawancara.

Wawancara dilakukan untuk mengkonstruksi gambaran agama, peristiwa, kegiatan, perasaan, motivasi, tuntunan, dan lain-lain. ${ }^{29}$ Wawancara mendalam tidak berstruktur seta tersamar dimaksudkan untuk lebih leluasa melacak ke berbagai segi dan arah guna mendapatkan informasi yang selengkap mungkin dan sedalam mungkin tanpa terganggu dengan setting sosial. kasi dengan baik. ${ }^{30}$ Penelitian ini bersifat eksploratif, analisis datanya dilakukan dengan menggunakan analisis deskriptif kualitatif.

\section{Fungsi dan Peran MUI Kota Padangsidimpuan}

\section{Fungsi}

Fungsi ini tetap sesuai keridornya untuk menjaga moralolitas dan aqidah masyarakat. MUI adalah gerakan moral. Dalam anggaran dasarnya MUI dengan tegas berfungsi sebagai wadah musyawarah dan wadah silaturrahmi para ulama, zuama dan cendekiawan muslim dalam mengayomi umat, mengembangkan dan mengamalkan ajaran Islam serta menggalang ukhuwah Islamiyah dalam kehidupan yang Islami, wadah yang mewakili umat Islam dalam hubungan dan konsultasi antar umat beragama serta pemberi fatwa kepada umat Islam dan pemerintah, baik diminta maupun tidak diminta.

Otoritas MUI Kota Padangsidimpuan tengah berhadapan dengan arus globalisasi, lembaga-lembaga yang memiliki ototritas yang diciptakan, munculnya organisasi sosial keagamaan Islam lainnya. Untuk itu fungsinya harus dikembangkan sesuai kualitas dan kuantitas persoalan hidup yang semakin berkembang.

\section{Peran MUI Kota Padangsidimpuan}

Dari sekian banyak aspek kehiduan sosial keagamaan dan kemasyarakatan, peneliti memilih empat bidang yang dijadikan objek penelitian kali ini yakni:

a. Sosial Keagamaan:

${ }^{29}$ Koentjaraningrat, Metode-Metode Penelitian Masyarakat, (Jakarta: PT Gramedia Utama, 1990), hlm. 129-30

${ }^{30}$ M. Burhan Bungin, Penelitian Kualitatif: Komunikasi, Ekonomi, Kebijakan Publik, dan Ilmu Sosial Lainnya, Edisi Kedua, (Jakarta: Kencana Prenada Media Group, 2011), hlm. 115-16 
1). Penentuan awal Ramadhan/hari raya. Otoritas MUI Kota Padangsidimpuan berhadapan dengan lembaga keagaman Islam lainnya seperti Muhammadiyah yang memiliki epistemologi tersendiri dalam menetukan awal Ramadhan dan penentuan hari raya id melalui ilmu hisab. Sedangkan metode ru'yah bagi kelompok ini adalah taqquly, bukan ta'abbudy. Bagi kelompok ini acuan dan standar adalah al-Qur'an dan Hadis bukan Pemerintah dan MUI. Namun demikian, tTerkait dengan perbedaan ini sangat dimungkinkan adanya kesamaan dan penyatuan persepsi antar lembaga dimasa datang. ${ }^{31}$ Ketua MUI Kota Padangsidimpuan telah menghimbau pemerintah dan seluruh komponen masyarakat Kota Padangsidimpuan untuk bersama dan sama-sama satu bahasa dan langkah dalam memulai awal Ramadhan dan juga lebaran sebagai simbol persatuan dan kesatuan umat Islam.32 Dalam hal ini Otoritas MUI Kota Padangsidimpuan lebih banyak diarahkan pada upaya peningkatan budaya hukum masyarakat.

2). Zakat Produktif. Otoritas MUI Kota Padangsidimpuan berhadapan dengan tingkat pendidikan masyarakat yang relatif masih rendah, pengamalan keagamaan yang masih kurang kuat, serta tuntutan kehidupan yang sulit. Muzakarah tentang zakat profesi telah dilaksanakan oleh MUI Kota Padangsidimpuan kepada PNS, sayang sekali diantara anggota MUI sendiri belum sama persepsinya tentang zakat ini, apalagi untuk memproduktifkannya. ${ }^{33} \quad$ Penyebab ini paling tidak karena tingkat pendidikan yang relatif masih rendah serta himpitan tuntutan ekonomi yang sangat mendesak. ${ }^{34}$ Dari sekian dana yang diproduktifkan lebih banyak tergantung dengan persoalan sikap kurang amanah masyarakat penerima bantuan sehingga dana dan program zakat produktif ini gagal. Nabi memang telah memberi peringatan akan hancurnya sekelompok orang jika sikap amanah mereka tidak diperpegangi dengan kuat. Mata ja'a al-sa'ah. Iza zahabat al-amanah, kapankah akan terjadi peristiwa hari kiamat --baik kiamat besar mauun kiamat kecil, jawabannya ketika sikap amanah tidak ada lagi. Kiamat kecil dalam hal ini identik dengan kehancuran atau kegagalan program zakat

${ }^{31}$ AN, Muhammadiyah, wawancara di Padangsidimpuan 2 Nopember 2015

${ }^{32}$ Azyumardi Azra dalam tulisannya pada harian Republika Nopember 2011 mengungkapkan kenapa umat Islam-khususnya di Indonesia-tidak bersatu di bawah satu otoritas keagamaan tunggal sehingga tidak ada lagi perbedaan-perbedaan, misalnya, yang paling mencolok, dalam penetapan awal dan akhir Ramadhan. Komaruddin Hidayat, orang yang selalu ingin berkelompok secara fanatik bisa jadi karena tidak cukup modal, baik secara sosial maupun intelektual sehingga cenderung mencari tumpangan hidup melaui cara-cara diluar common sense. Jika ini benar, duduk persoalannya menjadi jelas bahwa mereka yang masuk dalam kelompok fundamentalis maupun radikalis Islam itu hanyalah ikhtiar mencari "kenyamanan hidup palsu" di tengah persaingan hidup yang semakin sulit. Komaruddin Hidayat, dalam kata pengantar Islam Sosial sebuah Tafsir Atas Realitas karya Drs.H. Ahmad Supardi Hasibuan, MA, hlm.xxv

${ }^{33} \mathrm{ZEH}, \mathrm{MUI}$ Kota P, wawancara di Padangsidimpuan 15 Oktober 2015

${ }^{34}$ ASD, BAZDA Kota P, wawancara di Padangsidimpuan 1 Setember 2015 
produktif. ${ }^{35}$ Padahal ini sangat penting untuk mendukung perekonomian masyarakat. Diakui bahwaa pesan-pesan moral agama, seagung apapun, jika tidak relevan dengan kebutuhan objektif masyarakatnya, niscaya Islam hanya hadir sebagai dogma dan dongeng. Kesalahan terbesar yang dilakukan manusia adalah ketika manusia terpenjara oleh persepsi teks agama dan kurang mengeksplorasi konteks agama. Seharusnya agama hadir untuk membantu mengembangkan potensi kreatif yang terkandung dalam pribadi pemeluknya, bukan untuk melakukan perampasan martabat dan pemenjaraan krativitas individual. ${ }^{36}$ Dalam hal ini Otoritas MUI Kota Padangsidimpuan lebih banyak diarahkan pada upaya peningkatan kesadaran hukum masyarakat.

b. Sosial Kemasyarakatan:

1). Kesadaran Berlalu Lintas, Otoritas MUI Kota Padangsidimpuan sebagai pemilik otoritas murni berhadapan dengan otoritas yang dicipatkan yang kepolisian RI. Lembaga ini telah mulai “memfungsikan” otoritas MUI melalui pembinaan personil mereka menjadi ustaz yang memberi pencerahan melalui khutbah, ceramah di rumah ibadah masjid maupun mushalla dan masuk ke pesantren-pesantren. Polisi telah melakukan sosialisasi melalui kerjasama dengan masyarakat terorganisir maupun masyarakat yang tidak terorganisir. Selain sosialisasi ke lembaga-lembaga pendidikan dan masyarakat, kepolisian melihat bahwa sosialisasi yang paling tepat dan bagus adalah penindakan di lapangan. Untuk itulah idealnya seluruh anggota Polri adalah ustaz agar gerakan moral yang dilaksanakannya lebih efektif. ${ }^{37}$ Dalam hal ini Otoritas MUI Kota Padangsidimpuan lebih banyak diarahkan pada upaya peningkatan budaya hukum masyarakat.

2).Jam belajar masyarakat. Otoritas MUI Kota Padangsidimpuan berhadapan dengan lembaga yang memiliki otoritas yang diciptakan seperti Kementerian Agama Kota Padangsidimpuan dan Dinas Pendidikan Kota Padangsidimpuan. Kementerian Agama Kota mengurusi Madrasah negeri maupun swasta sedangkan Dinas Pendidikan Kota meng-handle lembaga pendidikan umum negeri maupun swasta. Kementerian Agama Kota umpamanya telah kembali menggerakkan program "magrib mengaji" dan kembali ke Surau. Program maghrib mengaji ini adalah secara psikologis-sosiologis, merupakan proses pembelajaran sebaya dan berkelompok agar anak-anak lebih semangat belajar dengan kawan sebaya, ada giri-giri sedikit, marsijottikan deba, serta ada

${ }^{35} \mathrm{RH}, \mathrm{BAZDA}$ Kota P, wawancara di Padangsidimpuan 15 Oktober 2015

${ }^{36}$ Komaruddin dalam kata pengantar Islam Sosial sebuah Tafsir Atas Realitas karya Drs.H. Ahmad Supardi Hasibuan, MA, hlm. XXIII

37TM, Polisi, wawancara di Padangsidimpuan 7 Oktober 2015 
kompetisisnya antar peserta. $^{38}$ Dalam hal ini Otoritas MUI Kota Padangsidimpuan lebih banyak diarahkan pada upaya peningkatan budaya hukum masyarakat.

Otoritas MUI Kota Padangsidimpuan dalam menjalankan perannya secara praktis tengah berhadapan dengan arus globalisasi yang membawa sains dan teknologi yang sangat berpengaruh, masuknya ideologi sekuler, sosialis, dan bahkan radikalis fundamentalis. meskipun saat kini program MUI Kota Padangsidimpuan masih lebih banyak berhubungan dengan peristiwa insidentil di masyarakat seperti persoalan narkoba, pementasan semi yang diperkirakan akan mengundang kemaksiatan, kafe-kafe, dan lomba motor-cross liar di jalan baru.

Contoh untuk daerah adalah Deli Serdang, situasi politik kini yang kurang harmonis antara MUI dengan pemerintah membuat lahirnya Majelis Ulama Daerah (MUD) sebagai rival dari MUI. ${ }^{39}$

Polisi ingin mendapatkan citra ulama sehingga mereka memersiapkan personilnya menjadi penceramah, khatib. Ini sekaligus menghindari birokrasi yang terkadang rumit dalam menjalin MoU antar lembaga. Polisi sudah memulai mengungkapkan persoalan lalu lintas pada khutbah Jum'at, sementara ustaz belum memulainya dan banyak yang masih berkutat pada perbincangan pahala, neraka, surga, dan neraka. Padahal seharusnya ustaz harus lebih banyak bicara tentang hal-hal yang berkaitan dengan kehidupan sehari-hari. ${ }^{40}$

Sangat alami ika makin banyak masyarakat, makin banyak jenis kelakuannya. Untuk itulah perbandingan polisi dengan rakyat idealnya 1:100, agar polisi dapat mengenal rakyat dengan baik termasuk dalam ciri dan cara mereka. Pada bagian lain action ustaz masih perlu dimaksimalkan di masyarakat, jangan terlalu banyak di podium demi peningkatan kesadaran hukum apalagi membudayakan hukum.. ${ }^{41}$

\section{KESIMPULAN}

April Carter dalam karyanya Authority and Democracy menuliskan bahwa setiap lingkup realitas kehidupan baik keluarga, politik, pekerjaan, pendidikan, dan sebagainya masing-masing membutuhkan tipe-tipe otoritas yang berbeda ataupun yang bersifat khusus. Tipe otoritas MUI Kota Padangsidimpuan saat ini tengah menghadapi ragam otoritas agama, lembaga --ketika terjadi ekspansi pendidikan tinggi Islam yang menghasilkan kian banyak lulusan yang by training ahli tentang Islam, peningkatan kelas menengah muslim yang mencari otoritas agama yang sesuai dengan latar belakang pendidikan dan lingkungan

${ }^{38}$ Is, masyarakat, wawancara di Padangsidimpuan 10 Oktober 2015, LHS, Kemenag Kota, Padangsidimpuan 27 September 2015.

${ }^{39}$ ZEH, MUI Kota Padangsidimpuan, wawancara di Padangsidimpuan 10 Oktober 2015

${ }^{40} \mathrm{RH}$, masyarakat, wawancara di Padangsidimpuan Nopember 2015

${ }^{41}$ AA, Polisi, wawancara di Padangsidimpuan 10 Oktober 2015 
sosio-ekonomis, adopsi liberalisasi politik dan ekspansi globalisasi, serta otoritas yang diciptakan dari lembaga lain sehingga otoritas itu terpencar.

Dalam banyak hal, otoritas MUI Kota Padangsidimpuan lebih banyak diarahkan pada upaya meningkatkan kesadaran hukum masyarakat, kemudian baru mengarah pada upaya meningkatkan budaya hukum masyarakat. Tentu indah dan sangat didambakan jika otoritas MUI Kota Padangsidimpuan untuk membina dan mengawal moral masyarakat dapat maksimal. 
186 Tazkir Vol. 01 No. 2 Juli-Desember 2015

\section{DAFTAR PUSTAKA}

AD/ART Majlis Ulama Indonesia

Ade Saptomo,"Budaya Hukum Indonesia yang Mendukung Pembangunan Hukum Nasional" dalam Komisi YUdisial RI, Problematika Hukum dan Peradilan di Indonesia, Jakarta: KYRI, 2014

Komisi YUdisial RI, Problematika Hukum dan Peradilan di Indonesia, Jakarta: KYRI, 2014

Ahmad Fanani, “Otoritas dalam Hukum Islam: Antara Tranformasi dan Krisis dalam Sistem

Negara Moderen" Justitia, vol. 7 No. 1/ Januari - Juni, 2010

April Carter, Authority and Democraty, diterjemahklan oleh Sahat Simamora, (Jakarta: Rajawali, 1985

Azyumardi Azra, Republika, 6 Januari 2011

Daniel W. Brown, Rethinking Tradition in Modern Islamic Thought, Cambridge: Cambridge University Press, 1996

Daniel W. Brown, Rethinking Tradition in Modern Islamic Thought, Cambridge: Cambridge University Press, 1996

Harian Waspada, Agustus 2014

Harian Waspada, Kamis, 2 April 2015

Ibnu Manzur, Lisan al-'Arab, Beirut: Dar al-Sadr, 1990

Jasser Audah, Maqasid al-Syariah in Philosophy of Islamic Law: A System Approach. LondonWashington, IIIT, 2007

Kamus Besar Bahasa Indonesia

Koentjaraningrat, Metode-Metode Penelitian Masyarakat, Jakarta: PT Gramedia Utama, 1990

Komaruddin Hidayat, dalam kata pengantar Islam Sosial sebuah Tafsir Atas Realitas karya Drs.H. Ahmad Supardi Hasibuan, MA, h.XXV

Komisi Yudiasial RI, Problematka Hukum dan Peradilan di Indonesia, Jakarta: KYRI, 2014

Komisi Yudisial RI, Problematika Hukum dan Peradilan di Indonesia, Jakarta: KYRI, 2014

Loren Bagus, Kamus Filsafat, Jakarta: Gramedia Pustaka Utama, 2000 
M. Amin Abdullah dalam Ahmad Norma Permata, (ed), Metode Studi Islam, Yogyakarta: Pustaka Pelajar, 2000

M. Burhan Bungin, Penelitian Kualitatif: Komunikasi, Ekonomi, Kebijakan Publik, dan Ilmu Sosial Lainnya, Edisi Kedua, Jakarta: Kencana Prenada Media Group, 2011

M. Sayuthi Ali, Metodologi Penelitian Agama: Pendekatan, Teori, dan Praktek Jakarta: PT Raja Grafindo Persada, 2002

Masdar Hilmy, Akar-Akar Transnasionalisme dalam Hizbut Tahrir Indonesia" dalam Islamica: Jurnal Studi Keislaman,Vol. 6, No. 1, September 2011

Qomarul Huda, “Otoritas Fatwa dalam Konteks Masyarakat Demokratis: Tinjauan atas Fatwa MUI Pasca Orde Baru" dalam M. Atha Mudzhar, dkk, Fatwa Majlis Ulama Indonesia (MUI) dalam Perspektif Hukum dan Perundang-undangan, Jakarta: Kemenag dan MUI Pusat, 2012 